УДК 621.771 .014

В.М. Самохвал, к. т. н., доцент, volsamokhval@gmail.com

М.М. Штода, к. т. н., доцент, maksshtoda@gmail.com

Дніпровський державний технічний університет, м. Кам'янське

К.К. Марченко, інженер, marchenokk@gmail.com

ПАТ «Дніпровський меткомбінат», м. Кам'янське

\title{
АНАЛІЗ МАТЕМАТИЧНИХ МОДЕЛЕЙ ОПОРУ ДЕФОРМУВАННЮ ДЛЯ УМОВ ВИСОКОШВИДКІСНИХ БЛОКІВ ДРОТОВИХ СТАНІВ
}

На основі аналізу відомих математичних моделей опору деформуванню пропонуються уточнені моделі Зюзіна та Андреюка. Для обох моделей рекомендовано визначати ступінь деформації через відносну зміну площі перерізу, а коефіцієнт, що враховує вплив швидкості деформації, розраховувати до значень иього параметру у $300 \mathrm{c}^{-1}$. При перевищенні иього значення коефічієнт приймають постійним, розрахованим для зазначеної величини швидкості деформаиіï. Крім иъього, для моделі Зюзіна запропонована, отримана з апроксимачії експериментальних даних, залежність для коефіцієнту, що враховує вплив швидкості деформачії. Уточнені моделі можуть бути використані для визначення опору деформуванню в умовах високошвидкісних блоків.

Ключові слова: опір метала деформуванню, математична модель, ступінь деформаиії, швидкість деформачїі, високошвидкісний блок, дріт.

Based on the analysis of known mathematical models of resistance to deformation, the updated models of Zyuzin and Andreyuk are proposed. For both models, it is recommended to determine the degree of deformation through the relative change in the cross-sectional area, and the coefficient, taking into account the influence of the strain rate, should be calculated to the values of this parameter $300 \mathrm{~s}^{-1}$. For large values of this parameter, the coefficient is assumed constant, calculated for the indicated value of the strain rate. In addition, for Zyuzin's model, a dependence obtained from the approximation of the experimental data for a coefficient that takes into account the influence of the rate of deformation is proposed. Updated models can be used to determine the resistance to deformation in the conditions of high-speed blocks.

Keywords: metal resistance to deformation, mathematical model, degree of deformation, strain rate, high-speed block, wire rod.

\section{Постановка проблеми}

Математичні моделі процесів прокатування широко використовуються для прогнозування технологічних параметрів та показників якості продукції, а також в системах автоматичного управління та обліку. Обов'язковою складовою таких моделей $є$ моделі для визначення опору металу деформуванню. Напруження текучості металу за певних умов деформування, яке узагальнено називають опір деформуванню, є одним 3 визначальних параметрів будь-якого процесу, зокрема і гарячого прокатування. Від точності визначення опору деформуванню значною мірою залежить точність визначення сили прокатування та інших енергосилових параметрів, які, у свою чергу, визначають характеристики обладнання, якість продукції та технікоекономічні показники виробничих процесів. Тому уточнення існуючих та розробка нових моделей для визначення опору деформування, які у більшій мірі відповідають сучасним технологічним процесам, залишається досить актуальною задачею.

\section{Аналіз останніх досліджень і публікацій}

Термін опір метала деформуванню вперше використав Е. Зібель [1] у 1910 році. Але системні дослідження кількісних залежностей опору метала деформуванню від параметрів цього деформування почались лише у другій половині 20-го сторіччя. Для умов гарячого прокатування найбільш відомі експериментальні дослідження Кука (Cook) [2], Дінника [3], Зюзіна [4, 5]. Ці дані і досі використовують для побудови більш точних моделей опору деформуванню. Дещо 
пізніше, у 70-ті роки минулого сторіччя, були запропоновані моделі Андреюка [6,7] та Шиди (Shida S.) [8]. Модель Л.В. Андреюка отримана на основі обробки експериментальних даних як власних пластометричних досліджень так і даних інших авторів. Всі наведені моделі враховують вплив чотирьох основних параметрів процесу, а саме хімічний склад металу, температура, швидкість та ступінь деформації. Відомі також моделі, що враховують більшу кількість параметрів. Зокрема модель Шварцбарта дозволяє враховувати залишкове зміцнення при багатоступеневому деформуванні [9].

Але ці моделі отримані для тогочасних умов гарячого прокатування. 3 часу розробки наведених моделей технологія та обладнання гарячого прокатування суттєво змінились. Зокрема, для дротових станів швидкість прокатування зросла з $15-25$ м/с до $100-150$ м/с. Тому в сучасних умовах досить актуальним стає питання точності відомих моделей визначення опору деформуванню та обгрунтування їх застосування. Прикладом робіт у цьому напрямку може бути запропонована Лі (Lee Y.) у 2002 році модифікація моделі Шиди [10]. Запропоновані зміни звелись до використання іншої моделі визначення впливу швидкості деформації, яка дозволяє розширити діапазон значень цього параметру до $3000 \mathrm{c}^{-1}$. Але, як зазначено у роботі [11], ця модель «пройшла» експериментальну перевірку лише для однієї марки сталі - хромо-нікельмолібденової сталі AISI 4340 (36CrNiMo4).

\section{Формулювання мети дослідження}

Відповідно, метою даної роботи є аналіз відомих математичних моделей опору деформуванню та можливостей їх застосування для умов високошвидкісних блоків дротових станів.

Для цього виконано порівняльний розрахунок опору деформуванню та енергосилових параметрів прокатування для умов чистового блоку стану 400/200 ПАТ «Дніпровського меткомбінату».

\section{Виклад основного матеріалу}

Аналіз виконано для моделей Зюзіна, Андреюка та Шиди-Лі (Shida S., Lee Y.) [10]. Геометричні параметри прокатування в десятимодульному блоці 200 наведено в таблиці 1, а технологічні параметри - в таблиці 2.

Таблищя 1. Параметри калібрів та показники формозміни при прокатуванні катанки діаметром 5,5 мм в блоці 200

\begin{tabular}{|c|c|c|c|c|c|c|c|c|c|c|}
\hline № & Розı & гіри каліб & & Розміри & розкату & Площа & Коеф. & Обти & тення & Розши- \\
\hline $\begin{array}{l}\text { моду- } \\
\text { лю }\end{array}$ & $\begin{array}{c}\text { ширина } \\
B_{\text {к }}\end{array}$ & $\begin{array}{l}\text { глибина } \\
\text { врізу } h_{\mathrm{sp}}\end{array}$ & $\begin{array}{c}\text { зазор } \\
g\end{array}$ & $\begin{array}{c}\text { висота } \\
h_{i}\end{array}$ & $\begin{array}{c}\text { ширина } \\
b_{i}\end{array}$ & $\begin{array}{c}\text { перерізу, } \\
A_{s}, \mathrm{Mм}^{2}\end{array}$ & $\begin{array}{c}\text { видовж. } \\
\lambda\end{array}$ & $\begin{array}{c}\text { макс. } \\
\Delta h\end{array}$ & $\begin{array}{c}\text { cep. } \\
\Delta h_{\text {сер }}\end{array}$ & $\begin{array}{c}\text { рення } \\
\Delta b\end{array}$ \\
\hline 0 & & & & 16,9 & 16,9 & 224,3 & & & & \\
\hline 1 & 23,65 & 4,6 & 1,94 & 11,14 & 20,65 & 185,5 & 1,209 & 5,76 & 4,29 & 3,75 \\
\hline 2 & 13,83 & 6,14 & 1,51 & 13,74 & 13,79 & 149 & 1,245 & 6,91 & 5,85 & 2,65 \\
\hline 3 & 18,89 & 3,5 & 1,85 & 8,85 & 16,97 & 120,4 & 1,238 & 4,94 & 3,75 & 3,23 \\
\hline 4 & 11,45 & 4,95 & 1,13 & 11,03 & 11,03 & 95,6 & 1,259 & 5,94 & 4,94 & 2,18 \\
\hline 5 & 16,85 & 2,70 & 1,22 & 6,62 & 13,9 & 76,0 & 1,258 & 4,41 & 3,2 & 2,87 \\
\hline 6 & 8,97 & 3,70 & 1,36 & 8,66 & 8,76 & 59,8 & 1,271 & 5,24 & 4,65 & 2,14 \\
\hline 7 & 13,56 & 2,10 & 1,06 & 5,26 & 10,97 & 48,2 & 1,241 & 3,50 & 2,51 & 2,31 \\
\hline 8 & 7,27 & 2,92 & 1,11 & 6,95 & 6,95 & 37,9 & 1,272 & 4,02 & 3,71 & 1,69 \\
\hline 9 & 10,24 & 1,60 & 0,99 & 4,19 & 8,75 & 30,2 & 1,255 & 2,76 & 2,00 & 1,8 \\
\hline 10 & 5,76 & 2,18 & 1,21 & 5,57 & 5,57 & 24,2 & 1,238 & 3,18 & 2,83 & 1,38 \\
\hline
\end{tabular}


Таблиця 2. Розрахункові технологічні параметри прокатування катанки діаметром 5,5 мм в блоці 200

\begin{tabular}{|c|c|c|c|c|c|c|c|c|c|c|}
\hline № & \multicolumn{2}{|c|}{ Швидкість } & \multirow{3}{*}{$\begin{array}{l}\text { Ступінь } \\
\text { деформ. }\end{array}$} & \multirow{3}{*}{$\begin{array}{c}\text { Темпе- } \\
\text { ратура, } \\
{ }^{\circ} \mathrm{C}\end{array}$} & \multirow{2}{*}{$\begin{array}{c}\text { Опір } \\
\text { деформ., }\end{array}$} & \multirow{4}{*}{$\begin{array}{l}\text { Коеф. } \\
\text { тертя }\end{array}$} & \multirow{4}{*}{$\begin{array}{c}\text { Коеф. } \\
\text { напруж. } \\
\text { стану }\end{array}$} & \multirow{4}{*}{$\begin{array}{c}\text { Середн. } \\
\text { тиск, } \\
\text { Н/мм² } \\
p_{\mathrm{cp}}\end{array}$} & \multirow{4}{*}{$\begin{array}{c}\text { Площа } \\
\text { конт. } \\
\text { мм² }^{2} \\
A_{s}\end{array}$} & \multirow{4}{*}{$\begin{array}{c}\text { Сила } \\
\text { прок. } \\
\text { кН } \\
F\end{array}$} \\
\hline MO & прокат. & деформ. & & & & & & & & \\
\hline ду & $\mathrm{M} / \mathrm{c}$ & $1 / \mathrm{c}$ & & & $\mathrm{H} / \mathrm{MM}^{2}$ & & & & & \\
\hline Лю & $V$ & $U$ & $\varepsilon$ & 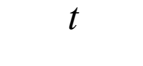 & $\sigma_{s}$ & & & & & \\
\hline 1 & 1 & & & & 26 & & & 348 & 32 & OO \\
\hline 2 & 16,13 & & & 9 & 26 & 6 & & 350 & $24^{\prime}$ & 86,81 \\
\hline 3 & 20 & & & & 26 & & & & 25 & 2,30 \\
\hline 4 &, 2 & 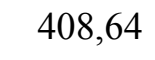 & & & & & & 35 & & 5,01 \\
\hline 5 & 31,97 & 646,989 & 16 & 993,168 & 258 & 0,241 & 14 & 366 & 190 & 69,78 \\
\hline 6 & טסק, & 7 & & 10 & & & & 35 & 13 & 49,25 \\
\hline 7 & 50,44 & 72 & 71 & 1008 & 244 & 0,238 & 8 & 35 & & 47,38 \\
\hline 8 &, 77 & 1319,14 & 49 & 1014,58 & 24 & 0 & 1,4273 & 349 & 97 & 34,24 \\
\hline 9 & 80,56 & 2042,06 & 9 & 1021,71 & 234 & 0,2 & 1,4973 & 351 , & 95, & 33,39 \\
\hline 10 & 99,48 & 2277,73 & 0,39223 & 1027,85 & 232,87 & 0,234 & 1,4575 & 339,409 & 68,5529 & 23,27 \\
\hline
\end{tabular}

Модель Зюзіна грунтується на визначенні базового опору деформуванню металу певного хімічного складу за «нормованих» умов, та врахуванні впливу відхилень від цих умов для дійсних значень температури, ступеню та швидкості деформації через термомеханічні коефіцієнти.

В роботі [5] модель запропонована у вигляді

$$
\sigma_{s}=\sigma_{o} \cdot k_{t} \cdot k_{\varepsilon} \cdot k_{u} \cdot
$$

Базовий опір деформуванню отримано за нормованих умов: температура $1000^{\circ} \mathrm{C}$; ступінь деформації 10\%; швидкість деформації $10 \mathrm{c}^{-1}$. Термомеханічні коефіцієнти представлені у вигляді графічних залежностей для діапазонів: $k_{t}: 700-1200^{\circ} \mathrm{C} ; k_{\varepsilon}: 5-50 \% ; k_{u}: 0,005-(100$, $250,300) \mathrm{c}^{1}$.

Для спрощення розрахунків використовують апроксимацію графічних залежностей. Наприклад, у довіднику [6] запропонована апроксимація узагальнених кривих для термомеханічних коефіцієнтів виразами:

$$
\begin{gathered}
k_{t}=0,57+0,0045(1200-t) \sqrt{\frac{1200-t}{t}} ; \\
k_{\varepsilon}=0,47 \sqrt{\varepsilon}-0,045 \varepsilon, \text { для } \varepsilon \leq 15 \% ; \\
k_{\varepsilon}=0,82+0,082 \sqrt{\varepsilon}, \text { для } \varepsilon>15 \% ; \\
k_{u}=0,80+0,065 \sqrt{U}, \text { для } U=1 \ldots 100 c^{-1} ; \\
k_{u}=0,80+0,085 \sqrt{U} \text {,для } U=100 \ldots 300 c^{-1},
\end{gathered}
$$

де $t$ - температура розкату на вході в осередок деформування, ${ }^{\circ} \mathrm{C} ; \varepsilon$ - ступінь деформації, як відношення абсолютного обтиснення до початкової товщини розкату, в \%; $U$ - швидкість деформації, $\mathrm{c}^{-1}$. 
Наприклад, при прокатуванні катанки діаметром 5,5 мм з сталі марки 08кп характерні параметри в першому модулі блока становлять: $U=200,875 \mathrm{c}^{-1} ; \varepsilon=32,317 \% ; t=964,8^{\circ} \mathrm{C}$ (таблиця 2), для яких розрахункові значення термомеханічних коефіцієнтів будуть дорівнювати:

$$
\begin{gathered}
k_{t}=0,57+0,0045(1200-964,8) \sqrt{\frac{1200-964,8}{964,8}}=1,093 ; \\
k_{\varepsilon}=0,82+0,082 \sqrt{32,317}=1,286 ; \\
k_{u}=0,80+0,085 \sqrt{200,875}=2,005 .
\end{gathered}
$$

За базового опору деформування 84 H/мм², дійсний опір за методикою Зюзіна буде дорівнювати

$$
\sigma_{S}=84 \cdot 1,093 \cdot 1,286 \cdot 2,005=236,7 \mathrm{H} / \text { мм }^{2} .
$$

Згідно графічних залежностей [3] за наведених параметрів прокатування опір деформуванню дорівнює приблизно $200 \mathrm{H} /$ мм $^{2}$. Отже, за методикою Зюзіна отримуємо завищені дані опору деформуванню.

Для з'ясування причин такого перевищення проаналізуємо розраховані значення термомеханічних коефіцієнтів. 3 графічних залежностей для коефіцієнтів, наведених в роботі [5, рис 45,46$]$ їх значення становлять. відповідно 1,095; 1,25; 1,7. Тобто, температурний та деформаційний коефіцієнти розраховані з достатньою точністю, а коефіцієнт швидкості деформування має завищені значення. Якщо використати значення коефіцієнтів, визначені з графіків, отримаємо величину опору, що відповідає експериментальним даним [3]

$$
\sigma_{S}=84 \cdot 1,095 \cdot 1,25 \cdot 1,7=195,5 \mathrm{H} / \mathrm{mм}^{2} .
$$

Методика Л.В. Андреюка передбачає використання степеневих залежностей для основних параметрів і має вид

$$
\sigma_{S}=S \cdot \sigma_{0} \cdot U^{a} \cdot(10 \cdot \varepsilon)^{b} \cdot\left(\frac{t}{1000}\right)^{c}
$$

де $S, a, b, c-$ коефіцієнти, значення яких визначають з таблиць; $\varepsilon-$ ступінь деформації, в долях одиниці.

Модель Андреюка рекомендована для діапазонів параметрів:

$$
U=0,01 \ldots 150 \mathrm{c}^{-1} ; \varepsilon=0,05 \ldots 0,30 ; \quad t=800 \ldots 1300^{\circ} \mathrm{C} .
$$

Для сталі марки 10 , як найближчої до сталі 08кп, коефіцієнти становлять, відповідно 0,$934 ; 0,125 ; 0,266 ;-2,46$. Базовий опір деформуванню становить 87,6 H/мм². Підставляючи ці значення у рівняння, для параметрів прокатування у першому модулі отримаємо

$$
\begin{gathered}
\sigma_{S}=0,934 \cdot 87,6 \cdot 200,875^{0,125} \cdot(10 \cdot 0,3232)^{0,266} \cdot\left(\frac{964,79}{1000}\right)^{-2,46}= \\
=81,82 \cdot 1,94 \cdot 1,366 \cdot 1,092=236,8 \mathrm{H} / \mathrm{MM}^{2} .
\end{gathered}
$$

Отже, незважаючи на відмінні значення коефіцієнтів, що враховують вплив ступеня та швидкості деформації, модель Андреюка також дає завищені значення опору деформуванню.

Модель Шиди-Лі визначає опір деформуванню як функцію ступеню деформації, швидкості деформування, температури та вмісту вуглецю і має вид

$$
\sigma_{s}=10 \cdot \sigma_{f} \cdot f \cdot\left(\frac{U}{10}\right)^{m} \cdot\left(\frac{U}{100}\right)^{m / 2,4} \cdot\left(\frac{U}{1000}\right)^{m / 15},
$$

де $\sigma_{f}-$ базове напруження текучості, яке визначають в залежності від вмісту вуглецю та температури; $f$ - складова, що враховує вплив ступеню деформації; $m-$ показник степені, який залежить від вмісту вуглецю та температури.

Модель передбачає визначення граничної безрозмірної температури для сталі, в залежності від вмісту вуглецю 


$$
t_{d}=\frac{0,95 \cdot(C+0,41)}{C+0,32} .
$$

Безрозмірну температуру деформування визначають з співвідношення

$$
t_{u}=\frac{t+273}{1000} .
$$

Далі, в залежності від співвідношення граничної та поточної безрозмірних температур, визначають величини $\sigma_{f}$ та $m$ :

для $t_{u} \geq t_{d}$

$$
\begin{gathered}
\sigma_{f}=0,28 \exp \left[\frac{5}{t_{u}}-\frac{0,01}{C+0,05}\right] ; \\
m=(-0,019 \cdot C+0,126) \cdot t_{u}+(0,075 \cdot C-0,05) ;
\end{gathered}
$$

для $t_{w}<t_{d}$

$$
\begin{gathered}
\sigma_{f}=0,28 \cdot q(C, t) \cdot \exp \left[\frac{5}{t_{d}}-\frac{0,01}{C+0,05}\right] ; \\
q(C, t)=30(C+0,9)\left[t_{u}-\frac{0,95(C+0,49)}{C+0,42}\right]^{2}+\frac{C+0,06}{C+0,09} \\
m=(0,091 \cdot C-0,154) \cdot t_{u}+(-0,019 \cdot C+0,207)+\frac{0,027}{C+0,320} .
\end{gathered}
$$

Складову $f$ для врахування впливу ступеню деформації визначають за формулою

$$
\begin{gathered}
f=1,3\left(\frac{\varepsilon}{0,2}\right)^{n}-0,3\left(\frac{\varepsilon}{0,2}\right), \\
n=0,41-0,07 \cdot C .
\end{gathered}
$$

Основною перевагою моделі (6) вважається широкий діапазон зміни швидкості деформування - до $3000 \mathrm{c}^{-1}$.

Для умов прокатування в першому модулі блоку згідно моделі Шиди-Лі отримаємо:

$$
t_{d}=\frac{0,95 \cdot(0,08+0,41)}{0,081+0,32}=1,1638 ; \quad t_{m}=\frac{964,79+273}{1000}=1,2378 .
$$

Так як $t_{u}>t_{d} \quad \sigma_{f}=0,28 \exp \left[\frac{5}{1,2378}-\frac{0,01}{0,08+0,05}\right]=14,725$;

$$
m=(-0,019 \cdot 0,08+0,126) \cdot 1,2378+(0,075 \cdot 0,08-0,05)=0,11 \text {. }
$$

Складова $f: n=0,41-0,07 \cdot 0,08=0,4044$;

$$
f=1,3\left(\frac{0,3232}{0,2}\right)^{0,4044}-0,3\left(\frac{0,3232}{0,2}\right)=1,0937 .
$$

Підставляючи отримані значення до основного виразу моделі, отримаємо

$$
\begin{gathered}
\sigma_{S}=10 \cdot 14,725 \cdot 1,0937 \cdot\left(\frac{200,875}{10}\right)^{0,11} \cdot\left(\frac{200,875}{100}\right)^{0,11 / 2,4} \cdot\left(\frac{200,875}{1000}\right)^{0,11 / 15}= \\
=147,25 \cdot 1,0937 \cdot 1,4195=228,6 \mathrm{H} / \mathrm{MM}^{2} .
\end{gathered}
$$

Отже, модель Шиди-Лі також дає завищені значення опору деформування. Але таке перевищення має місце при традиційному визначенні ступеня деформації через відношення абсолютного обтиснення до початкової товщини розкату. В роботах $[11,12]$ ступінь деформації пропонується визначати не як відносне обтиснення, а як істинну деформацію по висоті (логарифм деформації по висоті) або як істинну об'ємну деформацію. Наприклад, істинна об'ємна деформація визначається з виразу 


$$
\varepsilon_{p}=\frac{2}{\sqrt{3}}\left(\varepsilon_{1}^{2}+\varepsilon_{2}^{2}+\varepsilon_{1} \cdot \varepsilon_{2}\right),
$$

де $\varepsilon_{1}=\ln \left(\frac{H_{1}}{H_{0}}\right) ; \quad \varepsilon_{2}=\ln \left(\frac{B_{1}}{B_{0}}\right)$.

Для умов прокатування в першому модулі отримаємо

$$
\begin{aligned}
& \varepsilon_{1}=\ln \left(\frac{11,14}{16,9}\right)=-0,417 ; \quad \varepsilon_{2}=\ln \left(\frac{20,65}{16,9}\right)=0,2 ; \\
& \varepsilon_{p}=\frac{2}{\sqrt{3}}\left(-0,417^{2}+0,2^{2}+(-0,417 \cdot 0,2)\right)=0,151 .
\end{aligned}
$$

Тоді складова, що враховує вплив ступеня деформації, буде дорівнювати

$$
f=1,3\left(\frac{0,151}{0,2}\right)^{0,4044}-0,3\left(\frac{0,151}{0,2}\right)=0,9343,
$$

а опір деформуванню $\sigma_{S}=147,25 \cdot 0,9343 \cdot 1,4195=195,3 \mathrm{H} / \mathrm{мм}^{2}$.

Розраховане значення опору деформуванню з достатньою точністю відповідає експериментальному значенню.

Отже, модель Шиди-Лі забезпечує більшу точність визначення параметру, що розглядається, але при цьому врахування основних факторів має відмінний характер. Перш за все, обчислення впливу ступеню деформації через показник істинної деформації, призводить до того, що умовний коефіцієнт для цього фактору має суттєво менші значення (менше одиниці). Крім цього, умовний коефіцієнт врахування швидкості деформації також значно менший ніж у перших двох моделях. Але це компенсується збільшення значення умовного базового опору деформуванню.

При цьому варто відзначити, що базова модель Шиди, запропонована ще 1969 року, має вид

$$
\sigma_{s}=10 \cdot \sigma_{f} \cdot f \cdot\left(\frac{U}{10}\right)^{m}
$$

Тобто, з порівняння моделей (6) та (14), можемо зробити висновок про відносно незначний вплив швидкості деформування в діапазоні високих значень цього параметру. Цей висновок підтверджується експериментальними даними [13, рис. 5.1, стор. 134], за якими «опір деформуванню зростає до швидкості деформування близько $300 \mathrm{c}^{-1} \gg$, а для більших значень залишається постійним.

Врахування такої особливості впливу швидкості деформування дозволяє використовувати відомі моделі розрахунку опору деформування для умов високошвидкісних блоків дротових станів після відповідного уточнення.

Так для моделі (1) пропонується замінити залежність (4) на іншу, отриману з апроксимації експериментальних даних для сталі марки 08кп [5]. Для всього діапазону значень швидкості деформування, представлених на графіках (від 0,005 до $300 \mathrm{c}^{-1}$ ) коефіцієнт впливу цього параметру апроксимовано залежністю

$$
k_{u}=1,009 \cdot U^{0,1455} .
$$

Для значень $U>300 c^{-1} \quad k_{u}=1,009 \cdot 300^{0,1455}=2,31=$ const.

Для моделі Андреюка (5) також можливе використання існуючого співвідношення для коефіцієнту, що враховує вплив швидкості деформації, тобто

$$
k_{u}=U^{0,125},
$$

але до значень $U \leq 300 c^{-1}$. Для більших значень швидкості деформації слід використовувати постійне значення

$$
k_{u}=300^{0,125}=2,04=\text { const } .
$$


Ще одним важливим висновком з аналізу моделі Шиди-Лі є те, що врахування істинного ступеню деформації забезпечує більш високу точність визначення опору деформуванню. Використання відносного обтиснення для оцінки ступеню деформації виправдане для умов станів з виробництва плоского прокату, де має місце відносно рівномірна деформація. Для станів довгомірного прокату, при наявності розширення металу, відносне обтиснення не може адекватно характеризувати ступінь деформації. В умовах блоків дротових станів, де використовується переважно система калібрів «овал-круг», уточнення впливу ступеню деформації можливе за рахунок застосування співвідношення (13) з моделі Шиди-Лі, або шляхом визначення цього показника через площу перерізу розкатів, що дозволяє врахувати як усереднену деформацію по висоті, так і розширення розкату

$$
\varepsilon=\frac{A_{\text {in }}-A_{\text {ex }}}{A_{\text {in }}},
$$

де $A_{i n}, A_{e x}$ - відповідно, площа розкату на вході в осередок деформації та виході з нього.

Використання співвідношення (17) забезпечує отримання значно менших значень ступеню деформації, в порівнянні з відносним обтисненням, що призводить до пропорційного зменшення опору деформації. Крім цього, визначена таким чином ступінь деформації впливає на показник швидкості деформації, що також призводить до зменшення опору деформуванню.

Таким чином, уточнена модель Зюзіна зводиться до послідовного використання залежностей (2), (17), (3), (15) та (1). Модель Андреюка передбачає використання наявних табличних значень термомеханічних коефіцієнтів, визначення ступеня деформації за співвідношенням (17), застосування обмежень (16) для визначення складової (умовного коефіцієнту) впливу швидкості деформації та завершується залежністю (5). Такі уточнення моделей дозволяють не відкидати їх через невідповідність допустимих значень параметрів, а використовувати для умов високошвидкісних блоків дротових станів за швидкостей деформації понад $300 \mathrm{c}^{-1}$.

Для перевірки можливості використання наведених уточнень моделей Зюзіна та Андреюка, тобто перевірки адекватності уточнених моделей, виконали розрахунки опору деформування та сили прокатування для умов виготовлення катанки діаметром 5,5 мм на блоці 200 (таблиці 1,2).

Силу прокатування визначали за методикою В. К. Смірнова [14]. При цьому при визначенні коефіцієнту напруженого стану ступінь деформації визначали як відносне обтиснення, як це передбачено методикою. Результати розрахунків наведено в таблиці 3.

Таблищя 3. Опір деформуванню та сила прокатування, розраховані за уточненими моделями Зюзіна та Андреюка

\begin{tabular}{|c|c|c|c|c|c|c|c|c|c|c|c|c|c|c|c|}
\hline \multirow{2}{*}{$\begin{array}{l}\text { № } \\
\text { мо- } \\
\text { ду- } \\
\text { ля }\end{array}$} & \multicolumn{3}{|c|}{$\begin{array}{c}\text { Спільні } \\
\text { параметри }\end{array}$} & \multicolumn{6}{|c|}{ Модель Зюзіна } & \multicolumn{6}{|c|}{ Модель Андреюка } \\
\hline & $\begin{array}{l}t, \\
{ }^{\circ} \mathrm{C}\end{array}$ & $\varepsilon$ & $\begin{array}{l}U, \\
\mathrm{c}^{-1}\end{array}$ & $k_{t}$ & $k_{e}$ & $k_{u}$ & $\sigma_{S}, \mathrm{~N}$ & $\begin{array}{l}P_{\text {cp }}, \\
\text { МПа }\end{array}$ & \begin{tabular}{|l} 
F, \\
кН
\end{tabular} & $k_{t}$ & $k_{e}$ & $k_{u}$ & $\begin{array}{c}\sigma_{S} \\
\mathrm{MПа}\end{array}$ & $\begin{array}{c}P_{\text {cp }} \\
\text { МПа }\end{array}$ & $\begin{array}{l}F, \\
\text { кН }\end{array}$ \\
\hline 1 & 964,8 & 17 & 07,5 & 093 & 1,161 & 1,995 & 2,5 & 284,2 & 92,3 & 1,092 & 1,157 & 1,794 & 185,5 & 248,0 & 80,6 \\
\hline 2 & 70,8 & 19 & 130,9 & 1,077 & 1,184 & 2,053 & 219,8 & 290,2 & 71,9 & 1,076 & 1,197 & 1,839 & 193,8 & 255,8 & 63,4 \\
\hline 3 & 78,2 & 9 & 96,0 & 1,057 & 1,179 & 2,17 & 0 & 313,7 & 78,6 & 1,056 & 1,189 & 1,934 & 198,8 & 273,4 & 68,5 \\
\hline 4 & 35,4 & 0 & 31, & 037 & 1,192 & 2,2 & 231,7 & 9 & 57,1 & 1,037 & 1,212 & 1,975 & 203,1 & 274,2 & 5 \\
\hline 5 & 993,2 & 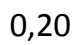 & 359,3 & נד1 & 1,191 & 2 & 233,7 & 3 & 10 & 17 & 1,210 & 40 & 2 &, 5 & 5 \\
\hline 6 & 00 & & 2020 & 4 & 1,199 & 2 & & כ. & & 998 & 1,223 & 2,040 & 203,8 & 284,7 & | 25,2 \\
\hline 7 & 1000 & & , & , & 1,181 & 2,300 & & $3 \angle L, 9$ & | 43,0 & 980 & 1,193 & |2,040 & 195,0 & 284,0 & 37,8 \\
\hline 8 & 1015 & $0, \angle 1$ & 96,2 & 0,955 & 1,199 & 2,300 & $2 \angle 1,1$ & 316,4 & 31,0 & 0,965 & 1,224 & 2,040 & 197,1 & 282,0 & 27,6 \\
\hline 9 & 1022 & 0,20 & 30,2 & 0,935 & 1,190 & 2,300 & 214,9 & 322,8 & 30,7 & 0,949 & 1,208 & 2,040 & 191,2 & 287,1 & 27,3 \\
\hline 10 & 28 & 0,19 & 15,3 & 918 & 1,179 & 2,300 & 209,2 & 305,9 & 20,9 & 0,935 & 1,190 & 2,040 & 185,6 & 271,3 & 18,6 \\
\hline
\end{tabular}


Розраховані значення сили прокатування порівнювали з експериментальними даними Ногуши (Noguchi Y.) [15]. Як видно з рисунку 1, обидві моделі, що перевіряються, забезпечують прийнятну точність визначення сили прокатування. Причому за моделлю Зюзіна отримуємо дещо більші значення, як опору деформуванню, так і сили прокатування, що характерно і для базових моделей. Різниця розрахованих за пропонованими моделями значень опору деформування не перевищує $30 \mathrm{H} / \mathrm{mm}^{2}$, що відповідає статистичним відхиленням при визначенні напружень текучості при пластометричних випробуваннях.

Таким чином, запропоновані уточнення моделей Зюзіна та Андреюка дозволяють підвищити точність визначення опору деформуванню. Уточнені відомі моделі можуть бути використані для визначення технологічних параметрів прокатування в умовах високошвидкісних блоків дротових станів.

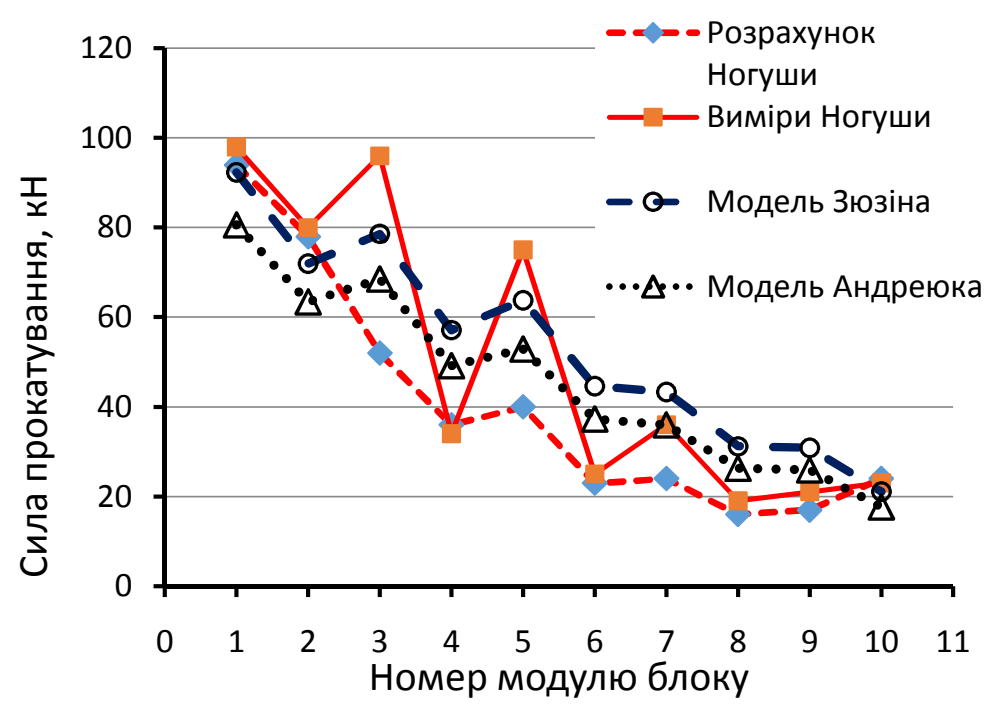

Рuc. 1. Порівняння експериментальних та розрахункових значень сили прокатування в десятимодульному блоці 200

\section{Висновки та перспективи подальших досліджень}

За результатами аналізу відомих моделей для визначення опору деформування розроблених Зюзіним, Андреюком та Шида-Лі встановлено, що в умовах високошвидкісних блоків всі моделі дають завищені значення параметру, що розглядається, при визначенні ступеню деформації через відносне обтиснення.

На прикладі моделі Шиди-Лі доведено, що для умов об'ємної деформації, яка має місце в системі калібрів «овал-круг», обчислення ступеню деформації як істинної об'ємної, забезпечує прийнятну точність визначення опору деформуванню.

Точність визначення опору деформуванню за відомими моделями Зюзіна та Андреюка може бути підвищена за рахунок уточнення визначення ступеня деформації, через відносну зміну площі перерізу, та за рахунок уточнення моделі впливу швидкості деформації шляхом впровадження граничних значень.

Запропоновані уточнені моделі Зюзіна та Андреюка забезпечують прийнятну точність визначення опору деформуванню, сили прокатування та інших технологічних параметрів прокатування у високошвидкісних блоках дротових станів.

\section{Список використаної літератури}

1. Зибель Э. Сопротивление деформации и истечение материала при прокатке. / Э. Зибель // Stahl und Eisen. - 1910. - № 51. - C. 1769-1775. 
2. Cook, P.M., "True Stress-Strain Curves for Steel in Compression at High Temperatures and Strain Rates, for Application to the Calculation of Load and Torque in Hot Rolling," Proceedings of the Conference on Properties of Materials at High Strain Rates, Institute of Mechanical Engineers. 1957. pp. 86-97.

3. Динник А. А. - В кн.: Теория прокатки. Материалы конференции по теоретическим вопросам прокатки. - М.: Металлургиздат, 1962. - С. 157-173

4. Зюзин В. И. Сопротивление деформации сталей при горячей прокатке / В. И. Зюзин, М. Я. Бровман, А. Ф. Мельников. - М.: Металлургия, 1964. - 270 с.

5. Третьяков А. В. Механические свойства металлов и сплавов при обработке металлов давлением: Справочник [Изд. второе, перераб. и дополн.] / А. В. Третьяков, В. И. Зюзин. - М.: Металлургия, 1973. - 224 с.

6. Андреюк Л. В. Аналитическая зависимость сопротивления деформации сталей и сплавов от их химического состава / Л. В. Андреюк, Г. Г. Тюленев, Б. С. Прицкер // Сталь. - 1972. - № 6. - C. 522-523.

7. Андреюк Л. В. Аналитическая зависимость сопротивления деформации металла от температуры, скорости и степени деформации / Л. В. Андреюк, Г. Г. Тюленев // Сталь. - 1972. - № 9. - C. $825-828$.

8. Shida S. Effect of Carbon Content, Temperature and Strain Rate on Compressive Flow Stress of Carbon Steels / Hitachi Research Laboratory Report. - 1974. - p. 1-9.

9. Шварцбарт Я. С. Моделирование процесса многоступенчатого деформирования на машине для кручения / Я. С. Шварцбарт, Г. С. Никитин, И. Г. Зуев // Заводская лаборатория. -1976. - № 4. - C. 48-56.

10. Lee, Y., Kim, B.M., Park, K.J., Seo, S.W. and Min, O., "A Study for the Constitutive Equation of Carbon Steel subjected to Large Strains, High Temperatures and High Strain Rates," Journal of Materials Processing Technology, 2002. - Volume 130-131. - pp. 181-188.

11. Biswas S. Simulation of Thermo-mechanical Deformation in High Speed Rolling of Long Steel Products: [A Thesis in Partial Fulfillment of the Requirements for the Degree of Master of Science]. - Worcester Polytechnic Institute. - 2003. - P. 172. https://web.wpi.edu/Pubs/ETD/Available/etd-1027103-203032/unrestricted/sbiswas.pdf

12. Lee Y. Analytic Model for the Prediction of Mean Effective Strain in Rod Rolling Process / Lee, Y., Kim, H.J. and Hwang, S.M. // Journal of Materials Processing Technology. - 2001. - Volume 114. - pp. 129-138.

13. Производство высокоуглеродистой катанки на металлургических агрегатах высшего технического уровня: [Научное издание] / В. И. Тимошпольский, Н. В. Андрианов, С. М. Жучков и др. - Минск: Бел. Наука, 2004. - 237 с.

14. Смирнов В. К. Калибровка прокатных валков: [Учебное пособие для студентов вузов] / В. К. Смирнов, В. А. Шилов, Ю. В. Инатович. - М.: Металлургия, 1987. - 368 с.

15. Noguchi Y. Characteristics of Continuous Wire Rod Roll Shaft and Precision Roll Shaft System / Noguchi Yukio, Harutoshi Ogai, Kunihiko Okamura, Takayoshi Hizume, Koji Tanabe, Koji Yoshimura. - Nippon Steel Technical Report. - 1999. - No 80, July. pp. 79-83. Available at: http://www.nssmc.com/en/tech/report/nsc/pdf/8016.pdf. 